\title{
Loss to follow-up of women with initial cervical cytology of ASC-US/LSIL in
}

\section{Tocantins, Brazil}

Perda de seguimento de mulheres com citologia cervical inicial de ASC-US / LSIL no Tocantins,

Brasil

Pérdida de seguimiento de mujeres con citología cervical inicial ASC-US / LSIL en Tocantins, Brasil

Recebido: 01/05/2021 | Revisado: 09/05/2021 | Aceito: 13/05/2021 | Publicado: 19/05/2021

Jucimária Dantas Galvão

ORCID: https://orcid.org/0000-0002-8773-9224 Secretaria Estadual de Saúde - Laboratório Central de Saúde Pública do Tocantins, Brazil E-mail: jucydg@uft.edu.br

Felipe Campos

ORCID: https://orcid.org/0000-0002-2724-1045 Universidade Federal da Bahia, Brazil E-mail: fcampos1205@gmail.com

Fábio Russomano

ORCID: https://orcid.org/0000-0001-7510-0485 Instituto Nacional de Saúde da Mulher, da Criança e do Adolescente Fernandes Figueira/FIOCRUZ, Brazil E-mail: fabio.russomano@iff.fiocruz.br

\begin{abstract}
Objective: The study aims to characterize loss to follow-up of women with initial cytological diagnosis of atypical squamous cells of undetermined significance, possibly non-neoplastic (ASC-US), or low-grade squamous intraepithelial lesion (LSIL), in Tocantins State, Brazil, from 2011 to 2013. Study Design: Cervical cytology data from the Information System on Uterine Cervical Cancer (SISCOLO) was used to identify women with initial diagnosis of ASC-US or LSIL in 2011. Nominal database record linkage was used to identify women with previous altered Pap smear results (who were excluded) and those who returned (versus failed to return) by the year 2013. Results: Record linkage identified 1,174 women with diagnoses of ASC-US (65.9\%) or LSIL (34.1\%) and without previous altered tests. According to the data, 55.9\% and 53.5\%, respectively, failed to undergo follow-up tests in the subsequent years. Conclusion: Failure to return for repeat cervical cytology suggests a missed opportunity for diagnosis and treatment of women with precursor lesions or cervical cancer not detected in the initial cytology, thus compromising the effectiveness of cervical cancer control in the State of Tocantins.
\end{abstract}

Keywords: Mass screening; Uterine cervical neoplasms; Cervical intraepithelial neoplasia; Women's health; Papanicolaou test; Early diagnosis.

\section{Resumo}

Objetivo: Descrever a perda de seguimento de mulheres com citologia ASC-US (Células Atípicas de Significado Indeterminado - possivelmente não neoplásicas) ou LSIL (Lesão Intraepitelial Escamosa de Baixo Grau) no Tocantins, no período de 2011 a 2013. Métodos: Dados do Sistema de Informação do Câncer do Colo do Útero (SISCOLO) dos exames citopatológicos foram utilizados para identificar mulheres que apresentavam resultados iniciais de ASC-US ou LSIL em 2011. Com a vinculação nominal por meio da ligação probabilística dos registros, identificou-se também aquelas que tinham resultados anteriores alterados (sendo excluídas), os retornos e não retornos até o ano de 2013. Resultados: Foram identificadas 1.174 mulheres com resultados ASC-US (65,9\%) ou LSIL $(34,1 \%)$ sem exames prévios alterados. Verificou-se, respectivamente, que 55,9\% e 53,5\% não realizaram novos exames nos anos subsequentes. Conclusão: O não retorno para a segunda citologia aponta uma provável perda de oportunidade de diagnóstico e tratamento de mulheres com lesões precursoras ou câncer não detectados na citologia inicial, comprometendo a efetividade do controle do câncer do colo do útero no Tocantins.

Palavras-chave: Programas de rastreamento; Neoplasias do colo do útero; Neoplasia intraepitelial cervical; Saúde da mulher; Teste de Papanicolaou; Diagnóstico precoce.

\section{Resumen}

Objetivo: Describir la pérdida de seguimiento de mujeres con ASC-US (células atípicas de significado indeterminado - posiblemente no neoplásicas) o LSIL (lesión intraepitelial escamosa de bajo grado) en Tocantins, de 2011 a 2013. Métodos: Sistema de datos de cáncer de cuello uterino El Sistema de Información (SISCOLO) de los exámenes citopatológicos se utilizó para identificar a las mujeres que tenían resultados iniciales de ASC-US o LSIL en 2011. 
Con la vinculación nominal a través de la vinculación probabilística de los registros, las que habían alterado los resultados anteriores (siendo excluidas), devuelve y no retornos hasta 2013. Resultados: 1.174 mujeres fueron identificadas con resultados ASC-US (65,9\%) o LSIL (34,1\%) sin exámenes previos alterados. Se encontró, respectivamente, que el $55,9 \%$ y el $53,5 \%$ no se sometieron a más exámenes en los años siguientes. Conclusión: No volver a la segunda citología apunta a una probable pérdida de oportunidad para el diagnóstico y tratamiento de mujeres con lesiones precursoras o cáncer no detectado en la citología inicial, comprometiendo la efectividad del control del cáncer de cuello uterino en Tocantins.

Palabras clave: Tamizaje masivo; Neoplasias del cuello uterino; Neoplasia intraepitelial cervical; Salud de la Mujer; Prueba de Papanicolaou; Diagnostico precoz.

\section{Introduction}

Cancer of the uterine cervix (CCU) is an important public health problem in Brazil, with relevant regional differences. The country's North and Northeast regions show the worst performance, exceeding by two to three-fold the mean national incidence of 15.85/100,000 women (INCA, 2017). In Tocantins State, located in the North of Brazil, cervical cancer is the most frequent neoplasia in females, with an estimated incidence of 33/100,000 women, greater severity of diagnosed cases and high mortality (Galvão, 2017; INCA, 2017).

The current CCU screening strategy in Brazil is cytopathological examination every three years after two negative annual tests, for women between 25 and 64 years of age (INCA, 2016). According to the Brazilian Guidelines for Cervical Cancer Screening, women with higher likelihood of presenting precursor lesions or initial cancer (high-grade squamous intraepithelial lesions or those involving the glandular epithelium - HSIL+) should be referred immediately for colposcopy, while women with lower likelihood of presenting such lesions (atypical squamous cells of undetermined significance, possibly non-neoplastic - ASC-US, or low-grade squamous intraepithelial lesions - LSIL) should be followed at the same service, repeating the cytopathological examination after at least six months (INCA, 2016).

The control of follow-up cervical cytology is affected by organizational deficiencies and difficulties in locating women via active search, resulting in an unknown loss to follow-up rate with a possible missed opportunity for the diagnosis and treatment of precursor lesions or initial cancer, undiagnosed in the initial examination (Galvão, 2017; INCA, 2016). A possibility for reducing loss to follow-up of these women is the identification of those at increased risk of presenting more important lesions, based on screening tests such as dual stain testing of proteins involved in viral oncogenesis or presence of oncogenic human papilloma virus (HPV) DNA (Cuschieri et al., 2018; de Melo et al., 2016).

These tests assume that the presence of oncogenic viral strains or proteins resulting from viral carcinogenesis increases the likelihood of the presence of a precursor lesion or cancer (Cuschieri et al., 2018; Donà et al., 2012), thus supporting immediate colposcopy for these women. However, evidence in the literature on the usefulness of dual stain testing for p16 and Ki67 and/or HPV DNA and, to a lesser extent, its applicability to screening or triage of women with altered cytology (Cuschieri et al., 2018; Donà et al., 2012), such tests are still not available in Brazil's Unified National Health System (SUS) and require the incorporation of technology, thus meriting studies applied to the Brazilian reality.

The database containing the records on the tests performed (Information System on Uterine Cervical Cancer, or SISCOLO in the Portuguese acronym) does not allow identifying the women that underwent the tests, since each record corresponds to one test, and there is no uniform and consistent record of the women's identifiers (Dias et al., 2010; Galvão, 2017; Reis Girianelli et al., 2009). Recently, new technologies have been applied that allow revisiting databases for different purposes from those for which the base was originally created, thus permitting new studies (Galvão, 2017; Tomazelli et al., 2018). Among these possibilities, probabilistic database linkage allows individualizing and correlating the information from one or more databases (or periods), based on information as patient's name, mother's name, and patient's date of birth. Probabilistic algorithms can be used in statistical modeling as a way of linking pairs of records, based on maximum entropy, Bayesian networks, clustering, and other programming techniques (Machado \&amp; Hill, 2004; Silva et al., 2013; Tomazelli et 
al., 2018).

Amongst other information, this data analysis strategy allows searching for each woman's test records over time (Galvão, 2017; Silva et al., 2013; Tomazelli et al., 2018). The current study aimed to identify the magnitude of loss to followup of women with ASC-US or LSIL cytology and possible factors associated with women's non-adherence to follow-up in Tocantins State, Brazil, using data available in the SISCOLO database and probabilistic record linkage.

The identification of a large volume of losses to follow-up may suggest the need for measures targeted to subgroups at increased risk of non-adherence or with higher likelihood of presenting preinvasive disease or cancer for referral to specialized services and colposcopy immediately after the initial test with diagnosis of ASC-US or LSIL.

\section{Methodology}

This was a descriptive retrospective study based on data from the SISCOLO, provided by the administration of the Tocantins State Health Department (SES-TO) and referring to the period from January 2008 to December 2013. The data were obtained from the forms for "Cytopathological Examination - Uterine Cervix", with the respective results. In addition to the variables for the test and the women's identification, the database contains information on certain sociodemographic variables, but with uneven completion rates and thus variable reliability.

Identification of the women used probabilistic record linkage (Machado \&amp; Hill, 2004) with a new variable created from the variables patient's name, mother's name, and patient's date of birth (Bastos, 2011; Galvão, 2017). Name variables were used in their phoneme format. After identification of the women and their tests, all those with a diagnosis of ASC-US or LSIL in 2011 were considered eligible. We excluded women with any cervical epithelial atypia in the three previous years (2008 to 2010), since they may have undergone a cytological examination in 2011 as a follow-up to a previous altered result.

For the women that were included, we conducted a search for a follow-up cervical cytology from 2011 to 2013 , assuming that it would be a follow-up test, even if conducted after the recommended period (6 months), and within 24 months after the initial cytology with an altered result. Women that had not undergone a repeat cytology in this period were defined as losses to follow-up (or failures to adhere to the national screening guidelines), and we proceeded to analyze the variables related to such non-adherence.

Women's age was calculated based on date of birth at the time of the initial cytology in 2011 and categorized in the following ranges: 24 years or younger, 25 to 64 years, and 65 years or older. In the analysis of factors potentially associated with loss to follow-up, we compared the age range of 29 years or younger versus 30 years or older.

The state is currently organized in eight health regions: Bico do Papagaio, Médio Norte Araguaia, Cerrado Tocantins Araguaia, Cantão, Capim Dourado, Amor Perfeito, Ilha do Bananal and Sudeste, considered this division in analysis. Information on previous cervical cytology was obtained from the variable "previous Pap smear". The first stage involved a descriptive analysis of the independent and outcome variables by initial diagnosis: ASC-US or LSIL. An exploratory bivariate analysis was performed, estimating relative risk for non-adherence to follow-up with 95\% confidence interval. Although we originally planned a multivariate analysis, we did not, since there was no association with more than one dependent variable in the bivariate analysis. All analyses used the SAS software, version 9.4, with significance level set at 5\% ( $\leq \leq 0.05)$.

The cervical cytology results were grouped as negative (no cytomorphological alteration), ASC-US, LSIL, and HSIL+ (for cases of high-grade squamous intraepithelial lesion - HSIL, alterations of undetermined significance, cannot rule out high-grade lesion - ASC-H, glandular cytomorphological alterations, and carcinoma).

The Institutional Review Board of the Institute of Collective Health, Federal University of Bahia ISC/IFBA (protocol no. 2.002.612), approved the study. The research was partially funded as Applied Research in the Unified National 
Health System - PPSUS-Tocantins Call for Projects n 01/2014 (FAPT/SESAU-TO/MS-DECIT/CNPq), concluded in October 2018.

\section{Results}

From 2011 to 2013, 193.497 women were identified, of whom 1.248 had cervical cytology performed in 2011 with diagnosis of ASC-US or LSIL. Of these, 74 had records of epithelial atypia in tests performed from 2008 to 2010 and were excluded, resulting in a total of 1.174 women for analysis (Figure 1).

Figure 1. Flowchart for database of women with altered initial cervical cytology (ASC-US or LSIL), in 2011.

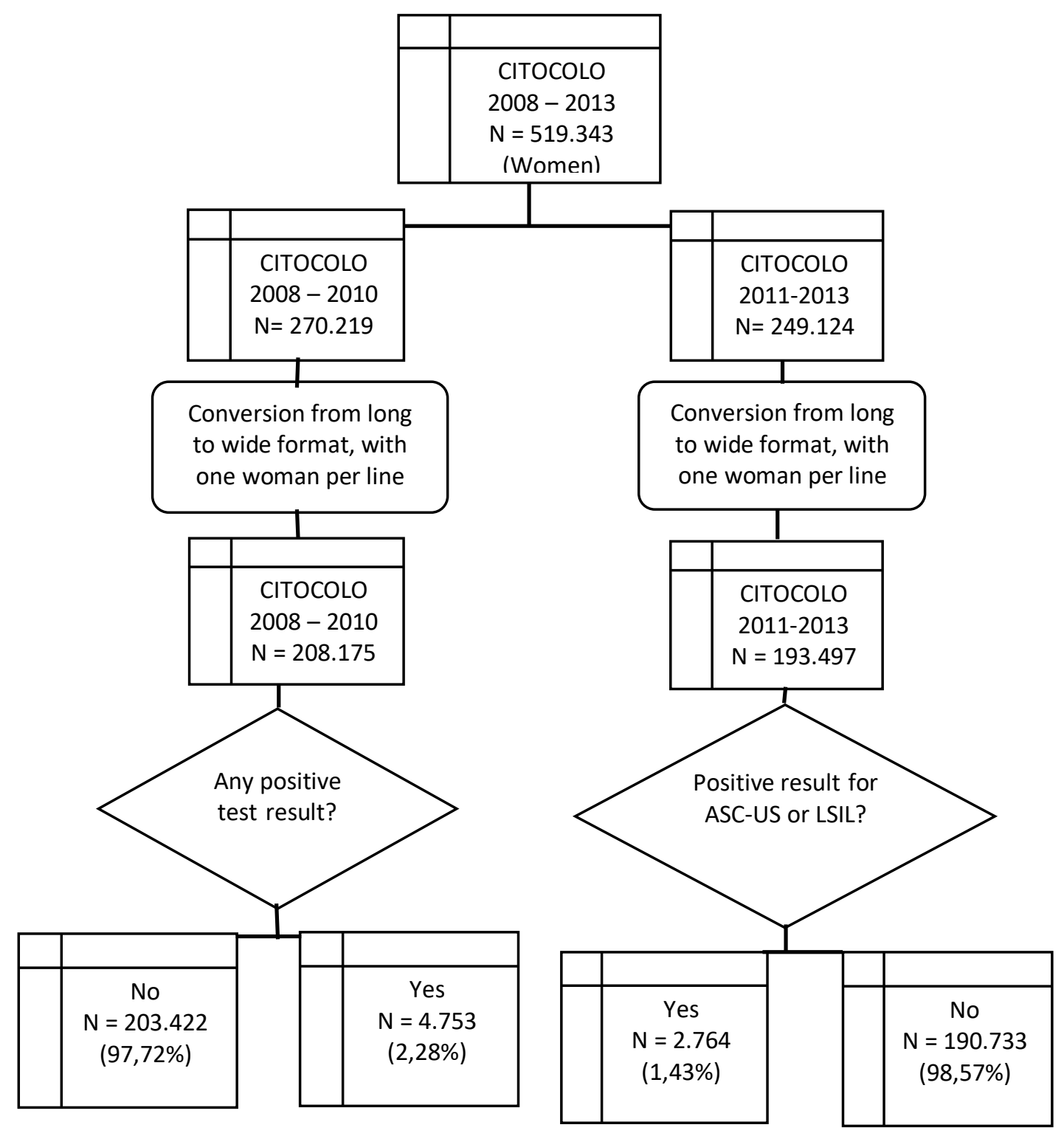

Fonte: Autores.

Table 1 shows the distribution of women according to initial diagnosis, age range, and health region where the cervical cytology was performed. ASC-US results were more frequent (65.9\%) than LSIL, especially in the 25-64-year age range (72.4\%). LSIL was diagnosed in $34.1 \%$ of the women with cytological atypias and was more frequent in younger women 
$(\leq 24$ years, 36.0\%). The largest proportions of women with these results were from the health regions of Capim Dourado (22.7\%) and Médio Norte Araguaia (25\%).

Table 1: Distribution of women according to initial diagnosis of ASC-US or LSIL, age range, and health region (SISCOLO, Tocantins State, Brazil, 2011).

\section{Initial diagnosis}

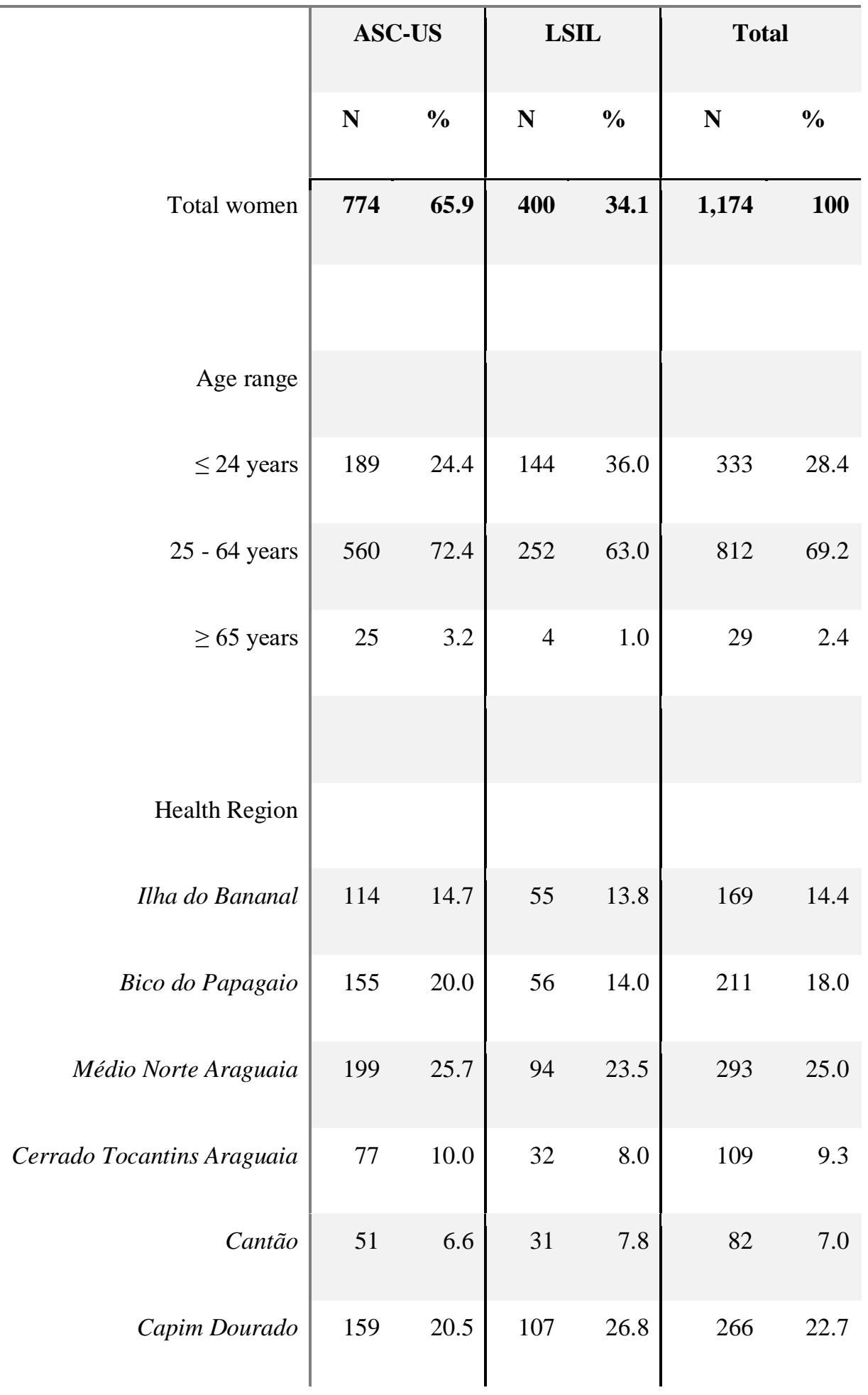


Research, Society and Development, v. 10, n. 6, e27910615660, 2021

(CC BY 4.0) | ISSN 2525-3409 | DOI: http://dx.doi.org/10.33448/rsd-v10i6.15660

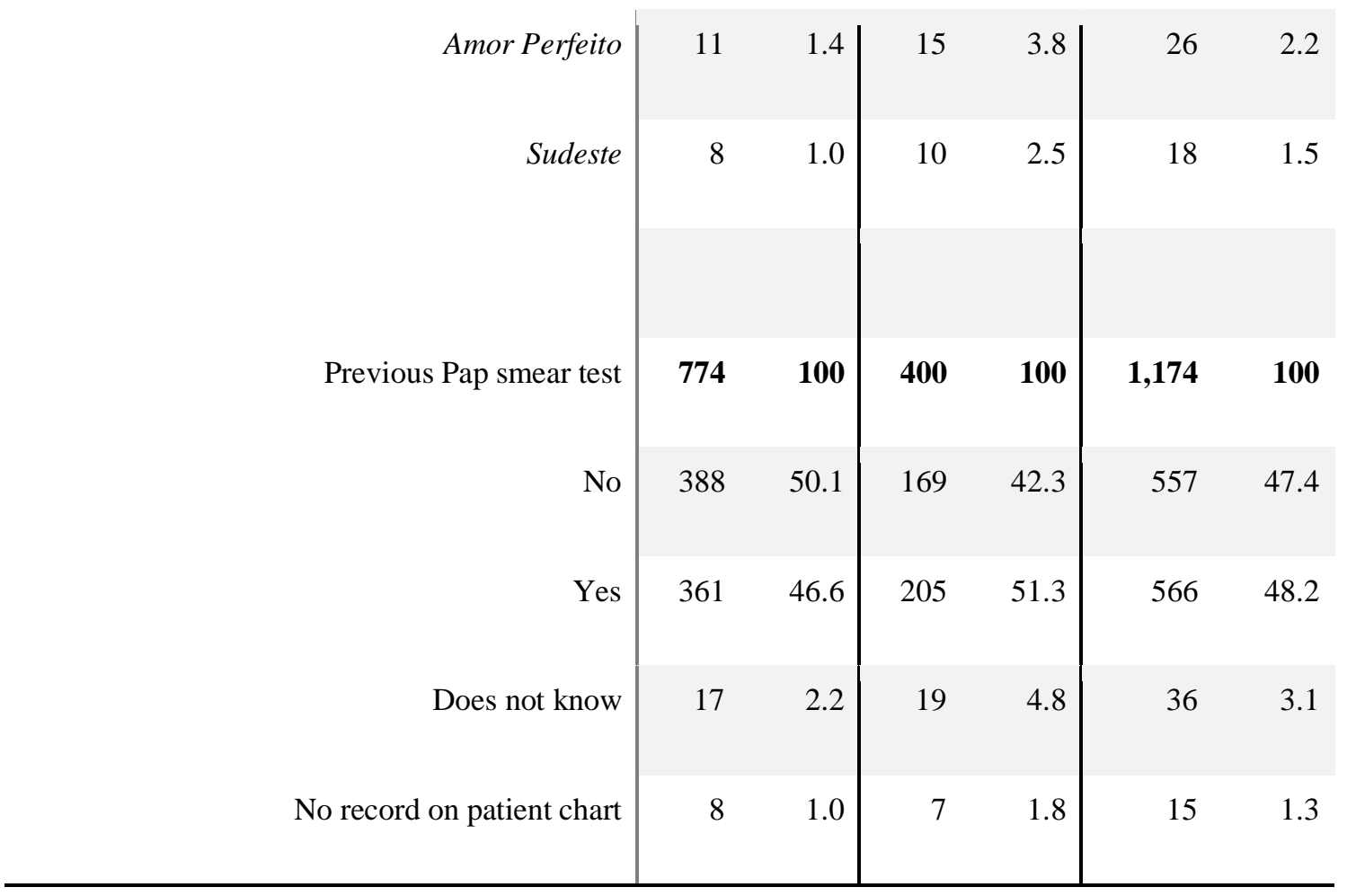

Fonte: Autores.

Table 2 shows the proportion of women that returned for follow-up cytology within 24 months after the initial examination. $55.1 \%$ of the women failed to return for a follow-up cytology within this time frame. Of those who returned, most (70.9\%) did so within 12 months, with no difference according to initial diagnosis (ASC-US versus LSIL). 
Table 2: Distribution of women who underwent a repeat test after altered initial test result and time to performance of repeat test (SISCOLO, Tocantins State, Brazil, 2011 to 2013).

\section{Initial diagnosis}

\begin{tabular}{|c|c|c|c|c|c|c|}
\hline & \multicolumn{2}{|c|}{ ASC-US } & \multicolumn{2}{|c|}{ LSIL } & \multicolumn{2}{|c|}{ Total } \\
\hline & $\mathbf{N}$ & $\%$ & $\mathbf{N}$ & $\%$ & $\mathbf{N}$ & $\%$ \\
\hline Without repeat test & 433 & $56 \%$ & 214 & $53.5 \%$ & 647 & $55.1 \%$ \\
\hline With repeat test & 341 & $44.1 \%$ & 186 & $46.5 \%$ & 527 & $44.9 \%$ \\
\hline Up to 6 months & 117 & $15.1 \%$ & 60 & $15.0 \%$ & 177 & $15.1 \%$ \\
\hline 7 to 12 months & 130 & $16.8 \%$ & 67 & $16.8 \%$ & 197 & $16.8 \%$ \\
\hline 13 to 18 months & 62 & $8.0 \%$ & 32 & $8.0 \%$ & 94 & $8.0 \%$ \\
\hline 19 to 24 months & 32 & $4.1 \%$ & 27 & $6.8 \%$ & 59 & $5.0 \%$ \\
\hline TOTAL & 774 & $100 \%$ & 400 & $100 \%$ & 1,174 & $100 \%$ \\
\hline
\end{tabular}

Fonte: Autores.

Of the 527 women who returned for follow-up cytology (44.9\% of the total), 479 (90.9\%) presented a negative result, 34 maintained the initial diagnosis of ASC-US or LSIL, and 14 (2.65\%) were diagnosed with HSIL+ (Table 3). 
Table 3: Distribution of outcomes (without repeat test and cytological diagnosis of second test, when performed within the study period) as a function of initial diagnosis (ASC-US or LSIL) (SISCOLO, Tocantins State, Brazil, 2011 to 2013 ).

\section{Initial diagnosis}

\begin{tabular}{|c|c|c|c|c|c|c|}
\hline \multirow[b]{2}{*}{ Follow-up } & \multicolumn{2}{|c|}{ ASC-US } & \multicolumn{2}{|c|}{ LSIL } & \multicolumn{2}{|c|}{ Total } \\
\hline & $\mathbf{N}$ & $\%$ & $\mathbf{N}$ & $\%$ & $\mathbf{N}$ & $\%$ \\
\hline Without new test & 433 & $55.9 \%$ & 214 & $53.5 \%$ & 647 & $55.1 \%$ \\
\hline With new test & 341 & $44.1 \%$ & 186 & $46.5 \%$ & 527 & $44.9 \%$ \\
\hline Negative & 308 & $39.8 \%$ & 171 & $42.8 \%$ & 479 & $40.8 \%$ \\
\hline ASC-US & 16 & $2.1 \%$ & 7 & $1.8 \%$ & 23 & $2.0 \%$ \\
\hline LSIL & 8 & $1.0 \%$ & 3 & $0.8 \%$ & 11 & $0.9 \%$ \\
\hline HSIL+ & 9 & $1.2 \%$ & 5 & $1.3 \%$ & 14 & $1.2 \%$ \\
\hline Total & 774 & $100 \%$ & 400 & $100 \%$ & 1,174 & $100 \%$ \\
\hline
\end{tabular}

Fonte: Autores.

The attempt to identify factors possibly related to loss to follow-up only considered the variables present in the database with completion rates greater than $50 \%$. Loss to follow-up was significantly associated with age lesser than 30 years (95\% CI 1.10 to 1.35 ) and lack of (or inability to report) a previous Pap smear test (Table 4).

Table 4: Association between failure to undergo repeat test and initial diagnosis, age range, health region, and information on last Pap smear test * (SISCOLO, Tocantins State, Brazil, 2011 to 2013).

\begin{tabular}{r|c|c|c|c|c}
\hline & $\mathbf{N}$ & $\%$ & $\mathbf{R R}$ & $\mathbf{9 5 \%} \mathbf{C I}$ & P-value $^{\dagger}$ \\
\hline Initial diagnosis & & & & \\
LSC-US & 433 & 55.94 & 1.04 & $0.93-1.16$ & 0.42 \\
LSIL & 214 & 53.5 & 1.0 &
\end{tabular}




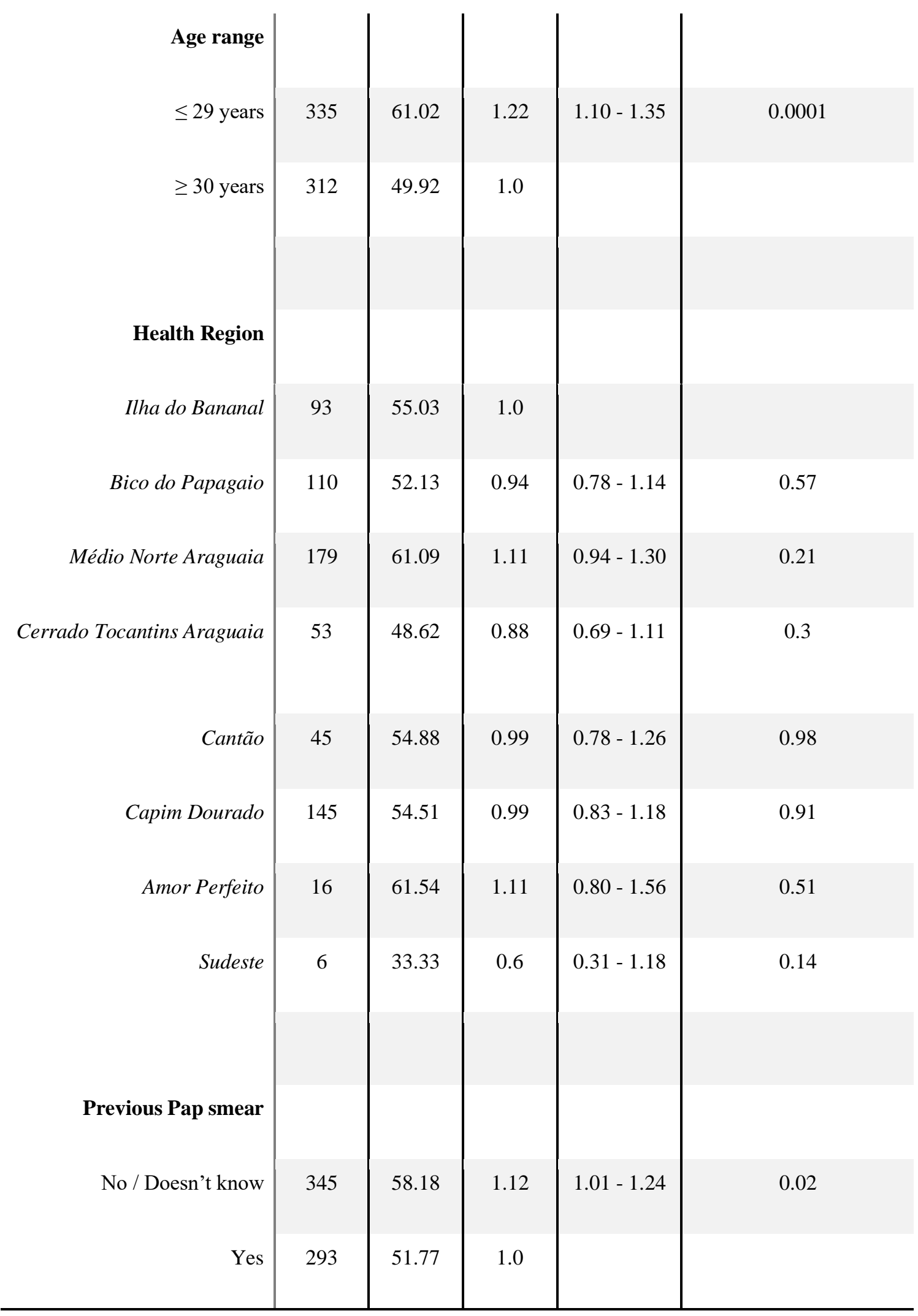

${ }^{*}$ Considering only variables in the database with more than $50 \%$ completion. ${ }^{+}$Chi-square. Fonte: Autores.

\section{Discussion}

This study focused on the identification of women who failed to return to health services for follow-up cervical cytology within 24 months after an initial diagnosis ASC-US or LSIL in 2011, when they should have done so within 6 months after the first test, as specified in the Brazilian Guidelines (INCA, 2016), in order to quantify losses to follow-up. Failure to 
undergo follow-up cytology was more frequent in younger women. No significant differences were observed in failure to return as a function of the initial test result (ASC-US versus LSIL).

Although a few women with altered initial cytology in the public Unified National Health System (SUS) may have done their follow-up cytology in the private health system, we consider this proportion negligible for the purposes of this study.

Identification of the 1.174 women was possible with probabilistic linkage of test records from the SISCOLO database. This method was necessary, since the database contains test records without a key that would allow deterministic linkage of the records to the same women over time (Galvão, 2017; Machado \&amp; Hill, 2004; Reis Girianelli et al., 2009; C. M. Ribeiro et al., 2018; Silva et al., 2013; Tomazelli et al., 2018) . This difficulty has been addressed in other studies in Brazil using the same methodology (Bastos, 2011; Dias et al., 2010; Galvão, 2017; Silva et al., 2013) (C. M. Ribeiro et al., 2018)(C. M. Ribeiro et al., 2018)(C. M. Ribeiro et al., 2018)(C. M. Ribeiro et al., 2018)(C. M. Ribeiro et al., 2018)(C. M. Ribeiro et al., 2018)[13]. The identification of this shortcoming in the SISCOLO database was one of the reasons for its reformulation and replacement by the SISCAN online system (Cancer Information System).

Our study's results show that the cervical cancer screening strategy is undermined in Tocantins State by nonadherence to the recommendation for a follow-up cervical cytology after a diagnosis of ASC-US or LSIL. A previous study in the same state of Brazil, aimed to assess cervical cancer screening, found that failure to undergo a follow-up examination when recommended can also be explained by local cultural and organizational factors (Galvão, 2017). This may involve women's unknowledge of the Pap smear test's importance, leading failure to return to receive the test result when the clinical complaint has been resolved and limitations imposed by individual values and difficulties in access to health units or inefficient active search of cases for performing the cytopathological examination (Amaral et al., 2014; Galvão, 2017; INCA, 2016; Silva et al., 2013).

Operational factors can also contribute to women's loss to follow-up, including difficulties in engaging health teams in the follow-up of cases that require repeat testing, as well as monitoring of the program's activities by local health administrators and laboratory services (Amaral et al., 2014; Galvão, 2017; INCA, 2016; L. Ribeiro et al., 2016).

The opportunistic model, based on women's spontaneous search for testing, poses major difficulties for controlling the disease (Galvão, 2017; INCA, 2016; L. Ribeiro et al., 2016). The data highlight the need to improve the health services' practices and management in order to guarantee follow-up of women with original diagnosis of ASC-US or LSIL, as recommended (INCA, 2016).

According to the data, among the women that underwent follow-up cytology, 1.2\% had a new test result suggesting greater severity (HSIL+) (Cytryn et al., 2009). This rate is relevant, considering the importance of diagnosis and the possibility of treating preinvasive lesions and initial cancer. Studies in Brazil, Iraq, and South Korea reported the frequency of alterations of cervical intraepithelial neoplasia grades II or III (CIN II/III) ranging from $0.8 \%$ to $1.85 \%$ in cases with ASC-US in previous results (Cytryn et al., 2009; Pity et al., 2012; Song et al., 2012). In women with previous cytology of LSIL, 21.3\% obtained CIN II/III as outcomes. In addition, cases with repeated results of ASC-US or LSIL may indicate higher likelihood of presenting preinvasive lesions (INCA, 2015, 2016).

Other studies have identified loss to follow-up of women who presented initial ASC-US. Galão et al. (Galão et al., 2012) observed a loss of $40.3 \%$ of all women with ASC-US in Rio Grande do Sul State, Brazil. The authors found that $3.1 \%$ of women who were retested in the subsequent three years presented HSIL+ as their new result, corroborating the need for follow-up of these cases (Galão et al., 2012).

A study conducted in a reference laboratory service in São Paulo, Brazil, reported failure to undergo follow-up cytology in $27.2 \%$ of women with initial ASC-US (Rosendo et al., 2019). Among those who underwent repeat cytology, $4.4 \%$ 
presented HSIL+, and $16.6 \%$ of the cases identified with biopsy (independently of having undergone repeat cytology) presented more serious lesions (Rosendo et al., 2019).

Notwithstanding differences in the frequency of more serious lesions between women with diagnosis of ASC-US versus LSIL, these studies show the importance of follow-up cytology, highlighting that the problem is not exclusive to Tocantins, but that it is also experienced in more developed regions of Brazil with lower cervical cancer incidence and mortality rates (Galão et al., 2012; Ginsburg et al., 2017; INCA, 2017; Rosendo et al., 2019).

The literature reports important local and regional cultural differences, with some regions presenting greater social vulnerability, lower levels of schooling, and worse preventive habits that can help explain the higher rates of loss to follow-up after an initial cytology with ASC-US or LSIL (Galão et al., 2012; Galvão, 2017; INCA, 2016; Rosendo et al., 2019) . These characteristics may explain the fact that we observed the highest losses to follow-up in the north of Tocantins (Médio Norte Araguaia) and the central region (Capim Dourado). Although these two regions include municipalities (counties) with outstanding farming and cattle-raising activity and better economic development, they also include towns with lower population density and lower human development indices (HDI) (Galvão, 2017).

The highest losses to follow-up were in younger women (under 29 years) and those who had not undergone a previous cytological examination or could not remember. The findings suggest that less informed women and those who seek health services with active gynecological complaints rather than for routine prevention of cervical cancer may be the ones with worst adherence to the recommendation to undergo follow-up tests. A possible strategy to reduce losses is to target activities to these women and to the health professionals involved in their care (Amaral et al., 2014; Galvão, 2017; INCA, 2016).

The study's limitations include the use of secondary data from the SISCOLO database, which showed inconsistencies and/or incompleteness in some fields in the test orders. Lack of completion can be attributed to gaps in the work processes, since the test orders and Pap smear samples were sent to the outsourced laboratory service providers, who transcribed the accompanying data on the test results, merely for billing purposes. The large number of variables with less than $50 \%$ completion compromised the analysis of factors associated with loss to follow-up and thus prevented suggesting strategies targeted more specifically to women at increased risk of failure to undergo repeat cytology.

\section{Conclusion}

More than half of the women with a cervical cytology of ASC-US or LSIL in Tocantins State, Brazil, in 2011 failed to undergo a repeat test, as recommended by the Brazilian Guidelines. Loss to follow-up is a missed opportunity for identifying and treating women with precursor lesions or $\mathrm{CCU}$, thereby jeopardizing the effective control of this disease.

Measures are needed to reduce loss to follow-up, especially among younger and less-informed women and those living in regions with lower human development or located farther from referral centers.

\section{Acknowledgments}

The authors wish to thank Fabiana Moura Mamede Alves, Fernanda Aleixo Dias, and Rodrigo Cândido de Souza for providing not only the data, but also learning opportunities and unconditional support for the research.

\section{Referências}

Amaral, A. F., Araújo, E. S., Magalhães, J. C., Silveira, É. A., Tavares, S. B. do N., \&amp; Amaral, R. G. (2014). Impacto da capacitação dos profissionais de saúde sobre o rastreamento do câncer do colo do útero em unidades básicas de saúde. Revista Brasileira de Ginecologia e Obstetrícia, 36(4), $182-187$. https://doi.org/10.1590/s0100-7203201400040004

Bastos, E. A. (2011). Estimativa da efetividade do programa de rastreamento do câncer do colo do útero no estado do Rio de Janeiro. 34(118). http://www.who.int/iris/handle/10665/39794 Cuschieri, K., Ronco, G., Lorincz, A., Smith, L., Ogilvie, G., Mirabello, L., Carozzi, F., Cubie, H., Wentzensen, 
N., Snijders, P., Arbyn, M., Monsonego, J., \&amp; Franceschi, S. (2018). Eurogin roadmap 2017: Triage strategies for the management of HPV-positive women in cervical screening programs. International Journal of Cancer, 143(4), 735-745. https://doi.org/10.1002/ijc.31261

Cytryn, A., Russomano, F. B., De Camargo, M. J., Zardo, L. M. G., Horta, N. M. S. R., De Fonseca, R. C. S. D. P., Tristão, M. A., \&amp; Monteiro, A. C. S. (2009). Prevalence of cervical intraepithelial neoplasia grades II/III and cervical cancer in patients with cytological diagnosis of atypical squamous cells when high-grade intraepithelial lesions (ASC-H) cannot be ruled out. Sao Paulo Medical Journal, 127(5), 283-287. https://doi.org/10.1590/S151631802009000500007

Dias, M. B. K., Tomazelli, J. G., \&amp; Assis, M. de. (2010). Rastreamento do câncer de colo do útero no Brasil: análise de dados do Siscolo no período de 2002 a 2006. Epidemiologia e Serviço de Saúde, Brasília, 19(3), 293-306. https://doi.org/10.5123/S1679-49742010000300011

Donà, M. G., Vocaturo, A., Giuliani, M., Ronchetti, L., Rollo, F., Pescarmona, E., Carosi, M., Vocaturo, G., \&amp; Benevolo, M. (2012). p16/Ki-67 dual staining in cervico-vaginal cytology: correlation with histology, Human Papillomavirus detection and genotyping in women undergoing colposcopy. Gynecologic Oncology, 126(2), 198-202. https://doi.org/10.1016/j.ygyno.2012.05.004

Galão, A. O., Vettorazzi, Luís Francisco Ramos-Lima, J., Mattos, J. C. de, \&amp; Naud, P. (2012). Prevalência e seguimento de exame citopatológico de colo uterino com atipias em células escamosas de origem indeterminada em um hospital universitário brasileiro. Clinical \&amp; Biomedical Research, 32(3), 296302. Galvão, J. D. (2017). Câncer do colo do útero no Estado do Tocantins: características do rastreamento e seguimento das mulheres na rede pública de saúde. [Universidade Federal da Bahia]. https://repositorio.ufba.br/ri/handle/ri/26013

Ginsburg, O., Bray, F., Coleman, M. P., Vanderpuye, V., Eniu, A., Kotha, S. R., Sarker, M., Huong, T. T., Allemani, C., Dvaladze, A., Gralow, J., Yeates, K., Taylor, C., Oomman, N., Krishnan, S., Sullivan, R., Kombe, D., Blas, M. M., Parham, G., ... Conteh, L. (2017). The global burden of women's cancers: a grand challenge in global health. The Lancet, 389(10071), 847-860. https://doi.org/10.1016/S0140-6736(16)31392-7

INCA. (2015). Avaliação de indicadores das ações de detecção precoce dos e cânceres do colo do útero e de mama - Brasil e Regiões, 2013. Ministério da Saúde - Secretaria de Vigilância Em Saúde, 1-30. www.inca.gov.br/utero

INCA. (2016). Diretrizes Brasileiras para o rastreamento Do Câncer Do Colo Do Útero. In Ministério Da Saúde: Vol. XXXIII (2nd ed., Issue 2). https://doi.org/10.1007/s13398-014-0173-7.2

INCA. (2017). Estimativa 2018 Incidência de Câncer no Brasil. Machado, C. J., \&amp; Hill, K. (2004). Probabilistic record linkage and an automated procedure to minimize the undecided-matched pair problem. Cadernos de Saúde Pública / Ministério Da Saúde, Fundação Oswaldo Cruz, Escola Nacional de Saúde Pública, 20(4), 915-925. https://doi.org/10.1590/S0102-311X2004000400005

Melo, F. L. P., Lancellotti, C. L. P., \&amp; da Silva, M. A. L. G. (2016). Expression of the Immunohistochemical Markers p16 and Ki-67 and Their Usefulness in the Diagnosis of Cervical Intraepithelial Neoplasms. Revista Brasileira de Ginecologia e Obstetrícia: Revista Da Federação Brasileira Das Sociedades de Ginecologia e Obstetrícia, 38(2), 82-87. https://doi.org/10.1055/s-0036-1571470

Pity, I. S., Shamdeen, M. Y., \&amp; Wais, S. A. (2012). Follow up of atypical squamous cell pap smears in iraqi women. Asian Pacific Journal of Cancer Prevention, 13(7), 3455-3460. https://doi.org/10.7314/APJCP.2012.13.7.3455

Reis Girianelli, V. I., Luiz Claudio Santos Thuler, I. I., Gulnar Azevedo Silva, I., \&amp; Reis Girianelli, V. (2009). Qualidade do Sistema de Informação do Câncer do Colo do Útero no estado do Rio de Janeiro Quality of Cervical Cancer Data System in the State of Rio de Janeiro, Southeastern Brazil. Rev Saúde Pública, 43(4), 580-588.

Ribeiro, C. M., Silva, G. A. e, Ribeiro, C. M., \&amp; Silva, G. A. e. (2018). Avaliação da produção de procedimentos da linha de cuidado do câncer do colo do útero no Sistema Único de Saúde do Brasil em 2015*. Epidemiologia e Serviços de Saúde, 27(1). https://doi.org/10.5123/S1679-49742018000100004

Ribeiro, L., Bastos, R. R., Vieira, M. de T., Ribeiro, L. C., Teixeira, M. T. B., \&amp; Leite, I. C. G. (2016). Rastreamento oportunístico versus perdas de oportunidade: não realização do exame de Papanicolaou entre mulheres que frequentaram o pré-natal. Cadernos de Saúde Pública, 32(6). https://doi.org/10.1590/0102-311x00001415

Rosendo, D. A., Lorente, S., Santos, C. M. dos, Ferreira, G. M., Canello, L. M., \&amp; Etlinger-Colonelli, D. (2019). Atypical squamous cells of indeterminate significance (ASC-US): follow-up of assay in Instituto Adolfo Lutz. Revista Brasileira de Análises Clínicas, 50(3), 265-269. https://doi.org/10.21877/2448-3877.201800680

Silva, M. G. P. da, Almeida, R. T. de, Bastos, E. A., \&amp; Nobre, F. F. (2013). Determinantes da detecção de atipias celulares no programa de rastreamento do câncer do colo do útero no Rio de Janeiro, Brasil. In Determinantes da detecção de atipias celulares no programa de rastreamento do câncer do colo do útero no Rio de Janeiro, Brasil (Vol. 34, Issue 2). Organizacion Panamericana de la Salud. http://www.scielosp.org/scielo.php?script=sci_arttext\&amp;pid=S1020-49892013000800005\&amp;lng=es\&amp;nrm=iso\&amp;tlng=pt

Song, J. S., Hwang, I., \&amp; Gong, G. (2012). Outcome of “atypical squamous cells” in cervical cytology: Follow- up assessment by loop electrical excision procedure. Korean Journal of Pathology, 46(4), 359-364. https://doi.org/10.4132/KoreanJPathol.2012.46.4.359

Tomazelli, J. G., Girianelli, V. R., \&amp; Silva, G. A. e. (2018). Estratégias usadas no relacionamento entre Sistemas de Informações em Saúde para seguimento das mulheres com mamografias suspeitas no Sistema Único de Saúde. Revista Brasileira de Epidemiologia, 21(0). https://doi.org/10.1590/1980549720180015 